\title{
Simulation Validation for Thermal Performance of Building Envelope Material in Humid Tropical Higland Climate
}

\author{
Huda Dawam Indana, Asri Dinapradipta, and Fransiskus XaveriusTeddy Badai Samodra \\ Department of Architecture, Institut Teknologi Sepuluh Nopember, Surabaya \\ e-mail: asdina_p@arch.its.ac.id
}

\begin{abstract}
Abstrak-Modeling and simulation using computer software are very important in supporting various types of research based on data calculations. In the research process, accuracy is needed between the simulation results and the results of field measurements. Thus, there is no significant difference between the two results. This study aims to verify and validate the result of field measurements and simulation using the ARCHIPAK 5.1 software. The variables studied focus on indoor air temperature and humidity. This research takes a case study in the village of Ranupane which is located within the Bromo Tengger Semeru National Park. There are 4 housing buildings measured which consist of two types of houses using fireplaces and two types of houses without fireplaces. All of the four houses are afterward modeled using the ARCHIPAK 5.1 software to validate the data results. From the measurement results, the field measurement data show a higher hourly temperature profile compared to the results of the simulation of the base case model. Two striking differences are the type of house without a fireplace which is showing the difference in the average temperature of $1-2 \mathrm{~K}$. While the type of house using fireplace shows the difference average temperature of 5,2-5,3 K. This occurs due to the internal heat gain input which the value is a slight difference between the result of field measurements and simulation of the base case model. This data verification and validation will be used as modeling optimal building configuration for housing in a humid tropical highland climate.
\end{abstract}

Kata Kunci-Ranupane, Building Thermal Performance, Archipak 1.5, Highland, Meteoblue.com Climate Data.

\section{INTRODUCTION}

$\mathrm{R}$ ESIDENTIAL buildings in Indonesia, especially in rural areas are often found using "lightweight" materials such as wood or bamboo. This is because it adjusts the availability of raw materials for building materials that generally exist in the area. Besides, residential buildings are designed to respond to the environmental climate, among others by installing natural ventilation with wide openings, utilizing the roof of the building as a shade, and adjusting the slope of the roof to humid tropical climate conditions [1]. Karyono also suggested that in designing buildings, local climatic conditions are considered and buildings are translated as tools to modify local climate problems [2]. One example is, the high environmental temperature in the tropics is responded to by using natural ventilation to meet the thermal comfort in buildings, while the high level of rainfall is responded to with a wide roof and so on.

Several studies on the thermal performance of residential buildings in the highlands have been carried out. However, there is not much research that addresses the thermal

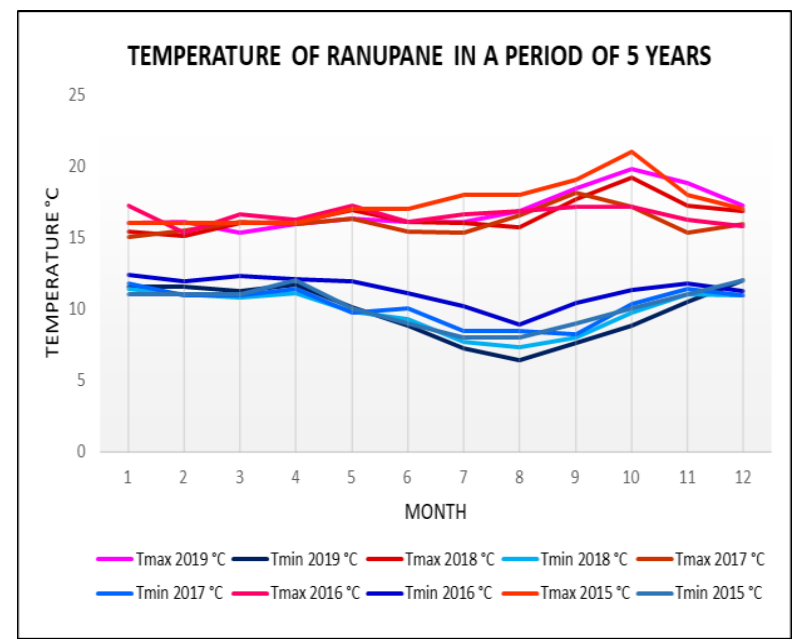

Figure 1. The temperature of Ranupane village in 5 years (meteoblue, 2015-2019).

performance of residential buildings, especially the differences in the envelope of building materials. Fitriaty evaluated the thermal performance of buildings and looked at the effectiveness of the traditional Tambi building design responses to climatic conditions in the highlands [3]. The results show that the Tambi traditional house has not been able to produce thermal comfort for its residents for 24 hours. This is caused by the limited ability of some building elements to adjust the climatic conditions outside the building. Another study was carried out by Alfred et al to evaluate the effect of Niang home design on the level of thermal performance by looking at the problem of underheating conditions in the surrounding environment [4]. Meanwhile, a study conducted by Nugroho tried to compare the thermal performance of a Wogo traditional house on the Flores Island and the thermal performance of the house with a contemporary design by architect Budi Fasial in Bandung [5]. Both of these houses have almost the same material characteristics, which are made from bamboo material, and both are also located in the highlands. The results of this study indicate that the traditional Wogo house is still less comfortable at night compared to the contemporary house owned by architect Budi Faisal in Bandung.

This paper is part of a research thesis that aims to determine the level of comfort and thermal performance of buildings in the highlands in the humid tropics, especially in Ranupane Village. There are 2 big questions raised in this study. First, how is the thermal performance of residential buildings in the humid tropical highlands with the influence of typology and 


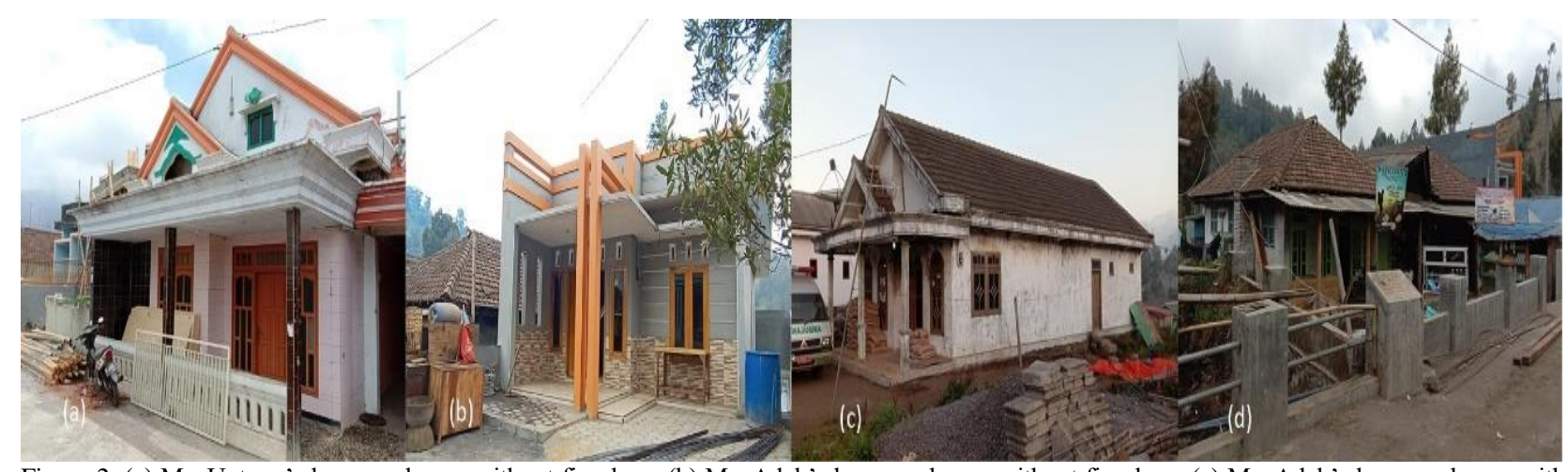

Figure 2. (a) Mr. Untung's house, a house without fireplace; (b) Mr. Adek's house, a house without fireplace; (c) Mr. Adek's house, a house with fireplace; (d) Mr. Buari's house, a house with fireplace.

Table 1.

A House Without A Fireplace, code HWF-1 and HWF-2

\begin{tabular}{llllll}
\hline \hline House Code: HWF-1 (Mr. Untung's House) & & \multicolumn{3}{l}{ House Code: HWF-2 (Mr. Adek's House) } \\
\hline Building Element & Dimension & Material & Building Element & Dimension & Material \\
\hline Floor & $60 \mathrm{~m} 2$ & Tile & Floor & $49 \mathrm{~m} 2$ & Tile \\
Wall & $15 \mathrm{~cm}$ & Brick & Wall & $15 \mathrm{~cm}$ & Hollow Conc. \\
& & & Total Opening & $11 \mathrm{~m} 2$ & Block \\
Total Opening & $9.8 \mathrm{~m} 2$ & Wood & Door & - & Wood \\
Door & - & Wood Frame with & Window & - & Wood Frame with \\
Window & - & Glass & & $2.85 \mathrm{~m}$ (high) & Glass \\
& & Gypsum Board & Ceiling & $15^{\circ}$ (pitch angle) & Asbestos Roof \\
Ceiling & $3 \mathrm{~m}$ (high) & Asbestos Roof & Roof & & Galvalum Frame \\
Roof & $35^{\circ}$ (pitch angle) & Wooden Frame & & & \\
& & & & & \\
& & & &
\end{tabular}

Table 2.

A House with A Fireplace, code HF-1 and HF-2

\begin{tabular}{|c|c|c|c|c|c|}
\hline \multicolumn{3}{|c|}{ House Code: HF-1 (Mr. Adek's House) } & \multicolumn{3}{|c|}{ House Code: HF-2 (Mr. Buari's House) } \\
\hline Building Element & Dimension & Material & Building Element & Dimension & Material \\
\hline Floor & $68 \mathrm{~m} 2$ & Tile & Floor & $69.4 \mathrm{~m} 2$ & Tile \\
\hline Wall & $15 \mathrm{~cm}$ & Brick & Wall & $15 \mathrm{~cm}$ & Brick \\
\hline Total Opening & $12.8 \mathrm{~m} 2$ & & Total Opening & $8.8 \mathrm{~m} 2$ & \\
\hline Door & - & Wood & Door & - & Wood \\
\hline Window & - & $\begin{array}{l}\text { Wood Frame with } \\
\text { Glass }\end{array}$ & Window & - & $\begin{array}{l}\text { Wood Frame with } \\
\text { Glass }\end{array}$ \\
\hline Ceiling & $3 \mathrm{~m}$ (high) & Gypsum Board & Ceiling & - & - \\
\hline Roof & $40^{\circ}$ (pitch angle) & $\begin{array}{l}\text { Conc. Tile } \\
\text { Wooden Frame }\end{array}$ & Roof & $35^{\circ}$ (pitch angle) & $\begin{array}{l}\text { Clay Tile Wooden } \\
\text { Frame }\end{array}$ \\
\hline
\end{tabular}

building envelope material in Ranupane village? Second, how can optimization of the use of insulation and building materials improve thermal performance in the humid tropical highlands in Ranupane Village? However, this paper is more focused on answering how validation of the results of field measurements and simulations should be used to carry out appropriate calibrations. To verify the performance results of the simulation model, it is necessary to calibrate the results of field measurements and base case simulations. In conducting calibration two main data are needed; simulation data in the form of a base case model and field measurement data [6].

Currently, the simulation software to determine the thermal performance of a building has been widely used by researchers and practitioners, because the simulation software makes it easier for them to evaluate their research or design. Therefore in the simulation process using computer software, accurate results are needed to achieve the desired results and to avoid significant differences between the results of computer simulations and the results of field measurements. For this reason, it is necessary to verify and validate $(\mathrm{V} \& \mathrm{~V})$ the simulation software that will be used in the research and design process [7]. In computational science, $V \& V$ can be simply defined as follows [8]: Verification is the process of assessing the accuracy of the results of computational models that can represent mathematical modeling, and validation is the process of determining whether the results of mathematical modeling can represent the state of physical conditions with sufficient accuracy. The purpose of simulation using computer software is to predict the actual physical condition by using computational modeling, so that manual measurements and calculations in the field do not need to be done.

Ranupane is the village with the highest location among other villages in Lumajang Regency, East Java, with an altitude of 2,200 meters above sea level and an area of $\pm 265 \mathrm{~h}$. As it is located within the Bromo Tengger Semeru National Park (TNBTS), Ranupane is also called an enclave village. This condition makes Ranupane village has a thermal comfort problem, which is cold discomfort, especially at night. The discomfort that occurs in tropical highland areas is generally 
The $6^{\text {th }}$ International Seminar on Science and Technology (ISST) 2020

July $25^{\text {th }} 2020$, Institut Teknologi Sepuluh Nopember, Surabaya, Indonesia

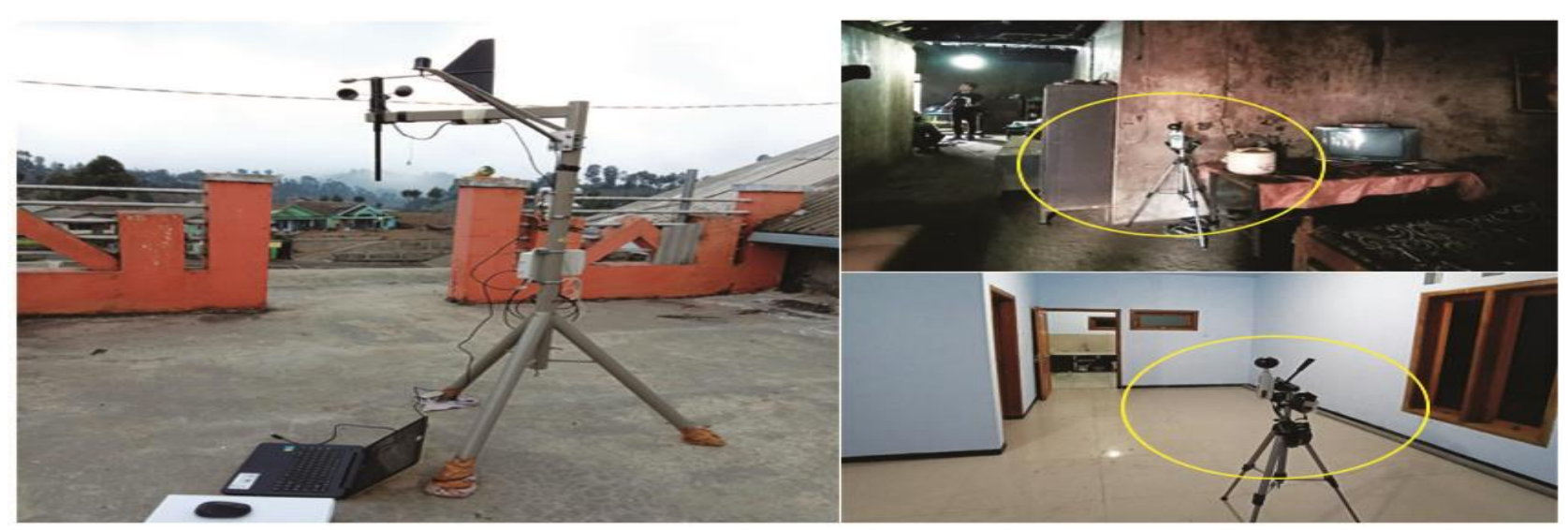

Figure 3. Placement of measurement tools.

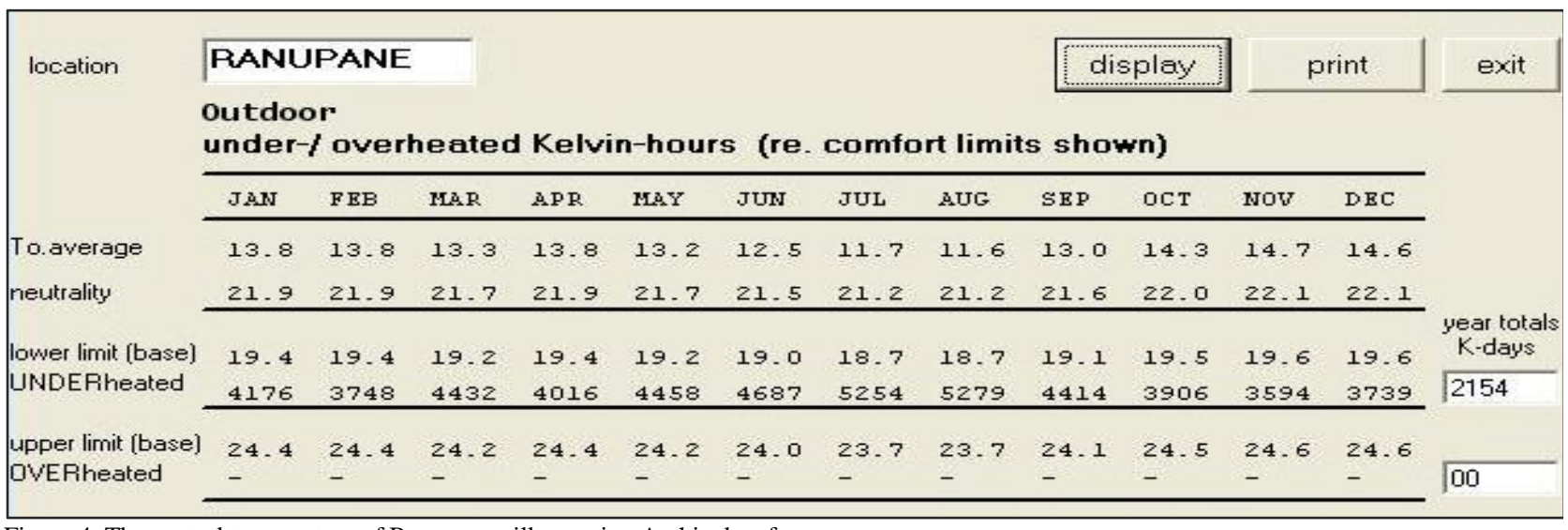

Figure 4. The neutral temperature of Ranupane village using Archipak software.

due to very cold temperatures, especially at night and excessive solar radiation that often results in direct body skin exposed to the sun [9]. The Ranupane community adapts to these conditions by setting up a fireplace in the house using woods obtained from the forest. Gradually this leads to a new problem, namely illegal forest encroachment that could threaten the preservation of nature in the National Park area. Therefore the Ranupane community's need for wood as a fireplace fuel and building material needs to be further evaluated.

Mirahimi in her research stated that building envelope has an important role in controlling energy consumption and thermal performance in buildings [10]. Therefore this research is more focused to see the comparison of the thermal performance of different building envelope materials in the field. For this purpose, one building model that can represent the buildings in Ranupane will be chosen as a base case optimization model.

\section{METHODOLOGY}

This study used several methods, including observation, field measurements, and simulations using computer software. Field observations were carried out by conducting interviews with the community to obtain information related to building materials used, the shape of the building model, population activities, and the level of thermal comfort felt by residents in the building. Meanwhile, field measurements were carried out to determine the building dimensions, air temperature, humidity, and wind speed. After the data from the initial identification were obtained, the data from observations and field surveys were later used as variables in the simulation using computer software.

This research used Archipak 5.1 software as a simulation modeling tool. The advantages of Archipak 5.1 include: first, it can present data breakdown from every element of the building so that analysis can be done on any part that gives a heat gain or heat loss distribution. Second, the value of air change per hour $(\mathrm{ACH})$ and internal heat gain can be entered in a constant or varied condition every hour. Third, the output from the simulation can take the form of a month or year unit, including monthly graphs of internal temperatures. Archipak 5.1 software can also be used as an option for research in remote areas or areas that are not reached by meteorological stations, as simulation software related to thermal or energy performance currently generally only has climate data in large cities. In small cities or remote areas, climate data input must still be done manually, where the inputted climate data is obtained from measurements using weather stations or from online climate data such as meteoblue.com.

\section{A. Description of case study building}

This research took a case study in the humid tropical highlands located in the village of Ranupane, East Java. Ranupane is an enclave village at the foot of Mount Semeru, East Java, with an area of \pm 265 hectares at an altitude of 2,200 meters above sea level. It is called an enclave village because it is located in the middle of Bromo Semeru Tengger 
The $6^{\text {th }}$ International Seminar on Science and Technology (ISST) 2020

July $25^{\text {th }}$ 2020, Institut Teknologi Sepuluh Nopember, Surabaya, Indonesia

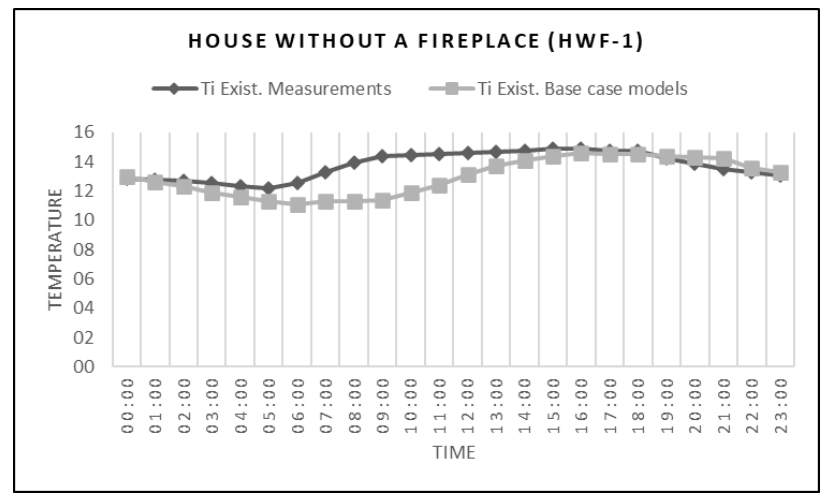

Figure 5. Comparison of Ti Existing measurement and Ti Existing base case model (HWF-1).

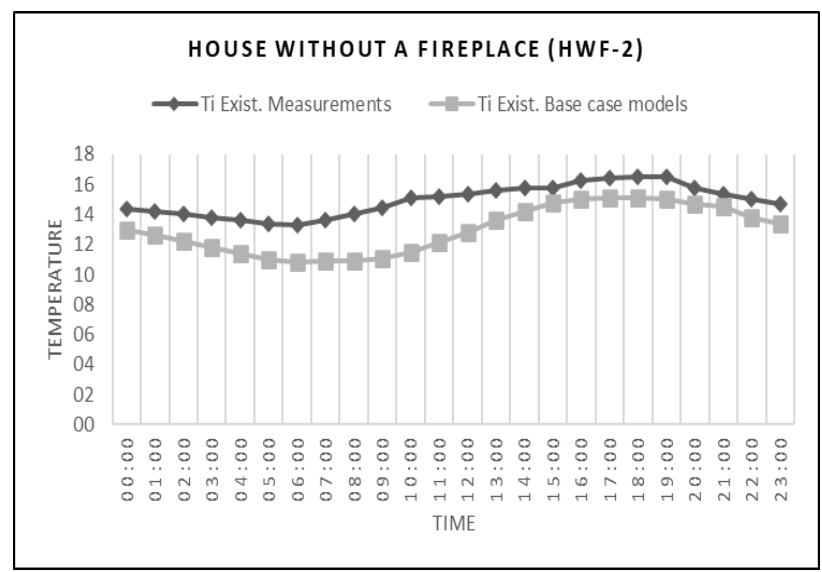

Figure 6. Comparison of Ti Existing measurement and Ti Existing base case model (HWF-2).

National Park (TNBTS). Judging from the topography, Ranupane village has a contour of hills and valleys. This condition affects the way Ranupane people build their houses. Generally, they build houses on low contour plains or ramps. But it is also not uncommon for some people to build houses on hillsides.

Because of its location in the mountains, the climatic conditions in Ranupane Village tend to be cold throughout the year. This is characterized by air temperatures ranging from $6^{\circ} \mathrm{C}-21^{\circ} \mathrm{C}$. During $2015-2019$, the climate in the village showed that the coldest weather occurred in August and the hottest in October (see figure 1). In August, the minimum temperature reached $6.4^{\circ} \mathrm{C}$ and the maximum temperature was $16.8^{\circ} \mathrm{C}$ with an average humidity of $78.1 \%$. Whereas in October, the minimum temperature reached $10^{\circ} \mathrm{C}$ and the maximum temperature was $18.8^{\circ} \mathrm{C}$ with an average humidity of $78.3 \%$. The highest radiation occurred in October with an average of 5,997 W/ m2. Meanwhile, rainfall was high, reaching 3,046 $\mathrm{mm} /$ year [11], with the rainy season usually occurring from November to May.

The annual climate data used for the simulation was taken from the website meteoblue.com which provides information on local climate data almost all over the world. This website is not only used for commercial needs, but also for academic research. The type of data provided is quite complete, including temperature $(2 \mathrm{~m})$, humidity $(2 \mathrm{~m})$ of rainfall, solar radiation, wind speed $(10 \mathrm{~m})$, wind direction, etc. The annual data collection was chosen online because there is no climate data for the Ranupane Village area at the nearest Meteorology

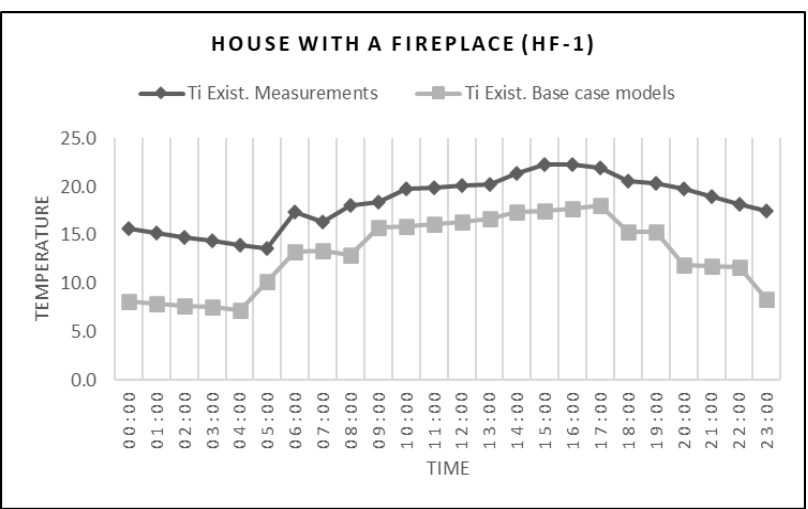

Figure 7. Comparison of Ti Existing measurement and Ti Existing base case model (HF-1).

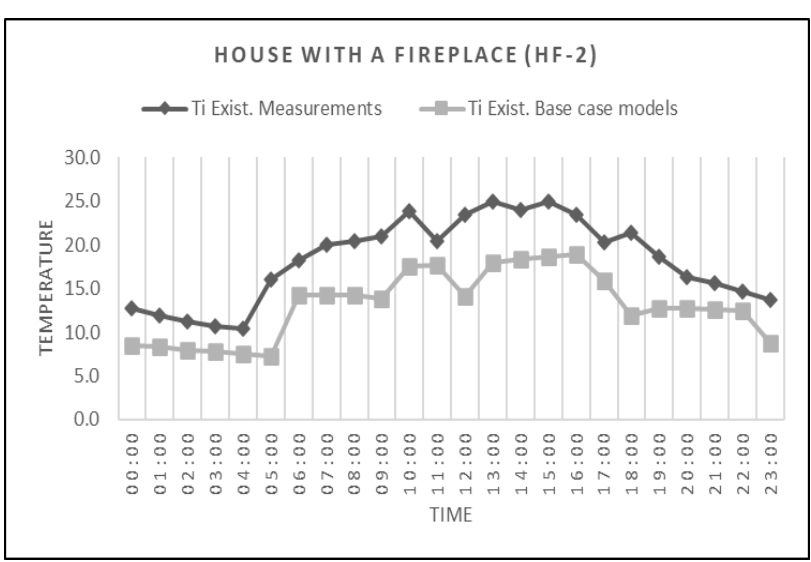

Figure 8. Comparison of Ti Existing measurement and Ti Existing base case model (HF-2).

Climatology and Geophysics Council (BMKG), which is the BMKG of Malang.

The research sample consisted of four housing units with different construction materials. Two housing units use red brick wall material and two other housing units use hollow concrete block wall material (see figure 2). There are also differences in the roofing material; some use asbestos roofs and some use clay tile roofs. As befits the Tengger Tribe, the four objects of the residence sampled in this study have almost the same spatial layout. They consist of a living room, bedroom, and kitchen. The guest room is not used properly because Ranupane residents usually lead their guests directly to the kitchen where they gather comfortably around the fireplace. Construction of building materials as a whole can be seen in table 1 and table 2 .

Measurement of the thermal condition of residential houses in this study was carried out from 12 to 17 September 2019. Measurements were taken in turns on each house due to limited equipment and time. The measured climate data included outdoor temperature, indoor temperature, humidity, wind direction, and wind speed. Outdoor temperature was measured using a Hobo Weather Station that was placed outside the building. To maintain tool safety, the Hobo Weather Station was installed on the roof of the building (see figure 3 ). In addition to measuring outdoor air temperature, this tool can also be used to measure humidity, wind direction, and wind speed. Temperature, humidity, and indoor wind speed were measured using a Hot Wire Anemometer and WBGT Data Logger. Each tool was placed in the space 
The $6^{\text {th }}$ International Seminar on Science and Technology (ISST) 2020

July $25^{\text {th }} 2020$, Institut Teknologi Sepuluh Nopember, Surabaya, Indonesia

commonly used by family members, which are the living room and kitchen (see figure 3 ).

\section{RESULT AND DISCUSSION}

Before the simulation results were analyzed further, the results of the field measurements were verified against the results of the base case model simulation. The aim was to determine whether there was a difference between the temperature profile of the field measurements and the temperature profile of the simulation results. If the results meet the requirements, it will be used to further analyze thermal performance in other base case models using macroclimate data obtained from meteoblue.com.

The thermal conditions in the study's sample building were identified by comparing neutral temperatures and external temperatures (macroclimate). From the results of calculations through the ARCHIPAK program taken in September (according to the time of measurement), a neutral temperature value of $21.2^{\circ} \mathrm{C}$ was obtained with a minimum limit temperature of $19.1^{\circ} \mathrm{C}$ and a maximum limit of $24.1^{\circ} \mathrm{C}$ (see figure 4 ). The temperature profiles of the measurement and simulation results show a difference, where the temperature value of the measurement results was higher than that of the simulation results. This happened because the base case measurement model was simplified and the data entered as derived from macroclimate data obtained from meteoblue.com. Besides that, the internal heat gain value in the field measurement was greater than the simulation. Maile, Fischer, and Bazjanac explained that in the implementation of simulations in which a model is compared to an object during direct measurement, there are various simplifications and reductions in input data, one of which is building data and other external data [12]. In other studies such as the one conducted by Kakon, the results of field measurements and the results of simulation measurements have a tendency of differences that can still be tolerated, which is equal to $2-4 \mathrm{~K}$ [13], so that the resulting value difference is still on the edge of fairness and can be used for further simulations.

To be able to see how big the difference between the measurement results and simulation results was, testing was done by comparing the temperature profile measured for 24 hours. In this simulation, the base case model consisted of four types of houses, two houses without a fireplace and two others with a fireplace. From the four houses, the temperature obtained from the field measurements was higher than the simulation results. But there was a striking difference in temperature values between houses without fireplaces and houses with fireplaces. Two base case models without a fireplace, namely the HWF-1 house and the HWF-2 house, had an average temperature difference between 1 and $1.9 \mathrm{~K}$ (see figures 5 and 6). This temperature difference is quite small because in both base-case models there as only a simplification of the base case model and no internal heat gain (fireplace) effect was included.

Meanwhile, when simulating a base case model using a fireplace, namely the HF-1 and HF-2 houses, the internal heat gain variable value in the form of a fireplace was included (see figures 6 and 7). The results show a striking difference, with an average temperature difference of $5.3 \mathrm{~K}$ for the $\mathrm{HF}-1$ base-case model and $5.2 \mathrm{~K}$ for the HF-2 base-case model. This large difference was likely not only due to the simplification of the base case model but also due to the internal heat gain input which as not the same as the existing one. Comparison of Ti Existing measurement and Ti Existing base case model (HF-2) can see Figure 8.

\section{CONCLUSION}

Based on the analysis and discussion above, several conclusions can be drawn, namely:(1)A comparison of measurement and simulation results in a base case model houses that doesn't use a fireplace (HWF-1 and HWF-2) has a small difference in value. This difference is natural because there is a simplification of the shape of the base case model; (2)A Comparison of measurement and simulation results in a base case model houses that use a fireplace has a large enough difference in value. This is not only due to the simplification of the base case model but also due to internal input of heat gain that is not the same as the existing conditions;(3)Although there are two differences between the base case models that use a fireplace and without a fireplace, the tendency of the temperature profile graph shows a similar trend. Thus, this paper provides a discussion of the results of verification to then be used as the basis for the next simulation; (4)For further research, field measurements in the form of internal heat gain input data such as occupancy, electrical and fireplace values need to be measured more thoroughly so that when inputting data on the Archipak software simulation, simulation results that are closer to the actual measurements are produced.

\section{REFERENCES}

[1] N.-C. Idham, "Arsitektur dan Kenyamanan Termal" 1st ed Yogyakarta: Andi-Offset, 2016.

[2] T.-H. Karyono, "Arsitektur dan KotaTropis Dunia Ketiga," 2013.

[3] P. Fitriaty, "Aspek Termal Rumah Tradisional Tambi," Institut Teknologi Sepuluh Nopember Surabaya, 2012.

[4] D.-D. Alfred, "Desain Rumah Niang Dalam Merespon Kondisi Termal di Dataran Tinggi," Institut Teknologi Sepuluh Nopember Surabaya, 2015.

[5] A.-M. Nugroho, "Arsitektur Tropis Nusantara, Rumah Tropis Nusantara Kontemporer," $1^{\text {st }}$ ed. Malang: UB Press, 2018.

[6] E. Fabrizio and V. Monetti, "Methodologies and Advancements in the Calibration of Building Energy Models," Open Access Energies 2015, 8, 2548-2574.

[7] W.-L. Oberkampf and T.-G. Trucano, "Verification and validation in computational fluid dynamics," progress in Aerospace Sciences 38 (2002)209-272, 2002

[8] I. Babuska and J.-T. Oden, "Verification and validation in computational engineering and science: basic concepts," computer methods in applied mechanics and engineering 193 (2004) 40574066, 2004

[9] O.-H. Koenigsberger, T.-G. Ingersoll, A. Mayhew, and S.-V. Sokolay, "Manual of Tropical Housing and Building. Part one: Climatic Design,"1974.

[10] S. Mirahimi, M.-F. Mohamed, L.-C. Haw, N.-L.-N. Ibrahim, W.-F. M. Yusoff, and A. Aflaki, "The effect of building envelope in the thermal comfort and energy saving for high-rise buildings in hot humid climate," Renewable and Sustainable Energy Review 53 (2016) 1508-1519, 2016

[11] Kecamatan Senduro Dalam Angka 2019, BPS Kabupaten Lumajang, 2019. 
IPTEK Journal of Proceedings Series No. (6) (2020), ISSN (2354-6026)

The $6^{\text {th }}$ International Seminar on Science and Technology (ISST) 2020

July $25^{\text {th }}$ 2020, Institut Teknologi Sepuluh Nopember, Surabaya, Indonesia

[12] T. Maile, V. Bazjanac, and M. Fischer, " A Method to Compare Simulated and Measured Data to Assess Building Energy Performance"
[13] A.-N. Kakon and N. Mishima, "The effects of building form on microclimate and outdoor thermal comfort in a tropical city," Journal of Civil Engineering and Architecture, Vol. 6. 1492-1503, 2012. 